\title{
GEOCHEMICAL TRENDS IN WHOLB-SEAM COAL CHANNEL SAMPLES FROM THE SYDNEY COALFIEID (UPPER CARBONIFEROUS), NOVA SCOTIA,
}

\author{
Brwin L. Zodrow \\ Department of GeologY, University College of Cape Breton \\ SydneY, Nova Scotia BIP 6L2
}

Date Received November 1, 1986

Date Accepted March 2, 1987

\begin{abstract}
From a series of whole-coal channel samples of the Sydney Coalfield of Nova Scotia, data on 30 metals and sulfur were obtained in order to study their stratigraphic variation, abundance, and origin. The data suggest the presence of distribution patterns (trends) that can be described in terms of concentration peaks occurring at the bottom or top of the channel samples. Complex or cyclical trends are observed in coal samples from the thicker $200 \mathrm{~cm}$ seams. These trends are genetically linked with deposition of pyrite and the depositional history of the peat swamps to form coal. Regional trends are not found in the data but there is a suggestion that some chalcophile metals are age-dependent and occur in the younger seams in the Point Aconi area.
\end{abstract}

On a prélevé des données sur 30 métaux et le soufre dans une suite d'échantillons de charbon global provenant de chenaux du bassin houiller de Sydney, en Nouvelle-Ecosse, afin d'en étudier la variation stratigraphique, l'abondance et l'origine. Leur traitement suggère la présence de patrons de distribution [tendances] sous la forme de pics de concentration qui se trouvent à la base ou au sommet des échantilions de chenal. On observe des tendances complexes ou cycliques dans les échantillons de charbon provenant des couches plus épaisses [200 cm]. L'origine de ces tendances est reliée au dépôt de la pyrite ainsi qu'à 1'histoire du remplissage des tourbières d'ò provient le charbon. A défaut d'avolr une tendance régionale, ces données conduisent à suggérer une dépendance vis-à-vis 1 'àge de certains minéraux chalcophiles qui se trouvent dans les lits plus jeunes de la région de Point Ancon1.

[Traduit par le journal]

\section{INTRODUCTION}

The Sydney Coalfield contains a sequence of mineable coal seams that were deposited in a floodplain environment (Figs. 1 and 2; Hacquebard, 1983 and references therein). Coals are geochemically very interesting as they are known to contain almost all of the chemical elements (Goldschmidt, 1935), and many elements (about 19) in the volatile "A" bituminous coal samples from Sydney show a greater abundance than that found in the average composition of the continental crust (cf. Taylor, 1964). Despite our general knowledge about the geochemical make-up of coals, 1ittle is known about the stratigraphical variations and distributions of the geochemical varlables, including ash and sulfur, In the coals from the Sydney Coalfield. Birk and Zodrow (in preparation) correlate certain aspects of coal geochemistry with mineral assemblages. Bulk geochemistry, as done on the coals for this study, does not directly address the question of coal mineralogy (cf. Given et al., 1981, for norm calculations). A knowledge of geochemistry is of considerable industrial, environmental. and geological interest as $1 t$ relates to the composition of coal dust, coal-ash washability, ash and sulfur contents (Walsh et al., 1969), and environment of coal deposition.

In the present paper, the emphasis is placed on examining the geochemical variables to address: 1. questions of stratigraphic varlability and distribution between and within the coal channel samples; and 2 . the origins of the variations. Conclusions lead to advances in statistical mean calculations and an understanding of pyrite as a contributor to the variation.

\section{MATERIALS AND NOMENCLATURE}

The Unnamed Seam, situated $8 \mathrm{~m}$ above the Lloyd Cove (-Bonar) Seam and documented by Zodrow (1985), was sampled in Brogan's open coal p1t at sample site '26' (see Zodrow, 1983, F1g. 1). The Point Acont Seam was sampled at localities 27,28 and 29 , the Lloyd Cove Seam in Brogan's pit and the Stubbart Seam underground in the Prince Mine. The Harbour Seam was laterally sampled:

(a) from the open p1t mine of the NovaCo company, located on the anticline found west of the Prince Mine, representing the erosional western margin of the Sydney Basin (Harbour Seam sample ' $W$ '. Table 2; F1g. 2); and

(b) from the Lingan and \#26 underground mines. representing the central portion of the coalfield (Harbour Seam sample 'CC', Table 2; F1g. 2).

The Backpit Seam was sampled at site 3, the Phalen underground in 126 Mine, and the Shoemaker and the McAulay Seams at sites 5 and 4 , respective1y.

In total, 10 successive coal seams were channel sampled (Fig. 2) by extracting a column of coal 8$14 \mathrm{~cm}$ wide and 5-12 $\mathrm{cm}$ deep from the entire thickness of the seams, with care being taken to avold clastic sediment contamination. Each whole-seam sample was subdivided into $15 \mathrm{~cm}$ lengths, disregarding microlithotype distribution (cf. Hawley, 1955), to obtain a sample population of 137. Bottom samples are generally less than $15 \mathrm{~cm}$ long. The entire sample amount of coal (up to $1,200 \mathrm{~g}$ ) 


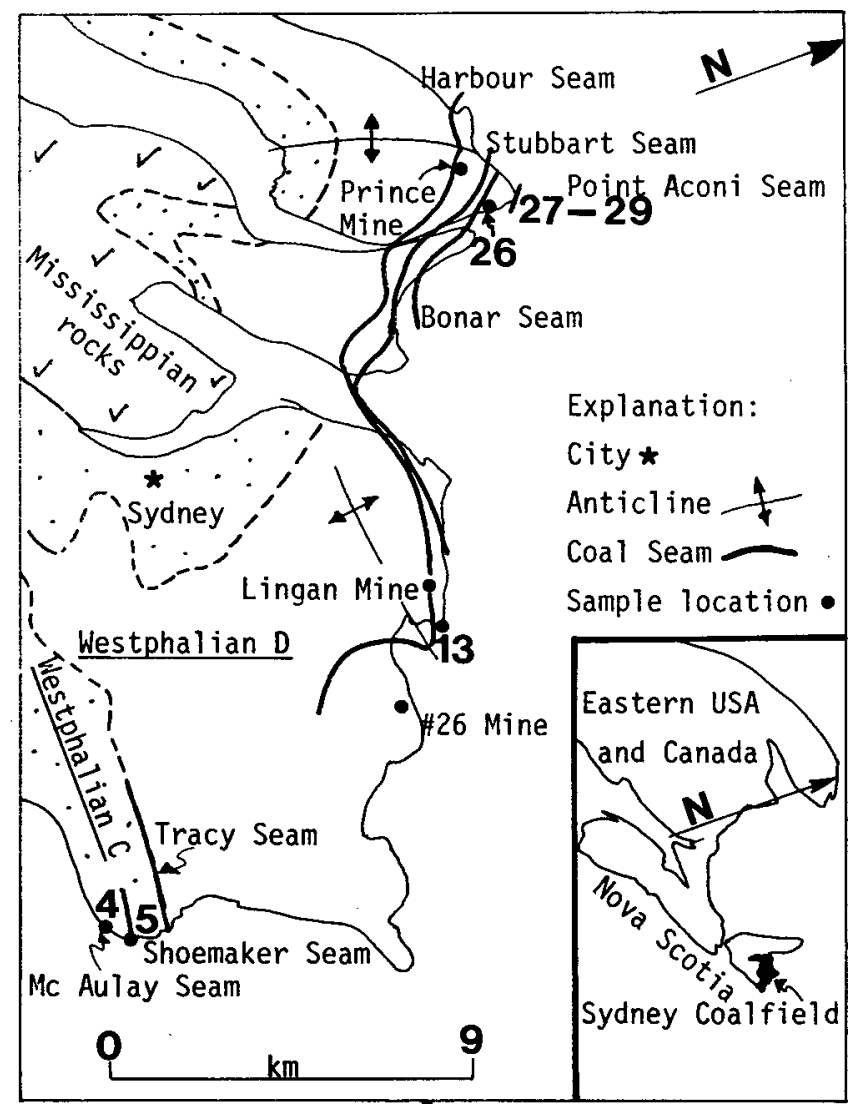

Fig. 1. Sample location map, Sydney Coalfield. [See Fig. 2 for further stratigraphic detall and the presence of lower Stephanian (1.e., Cantabrian) strata in the Point Aconi area.]

was dry-ground to pass through a $(-200)$ standard Tyler mesh screen (<75 micrometres), and a sample portion ashed for 12 hours at a temperature not exceeding $450^{\circ} \mathrm{C}$. For each of the 137 samples, 31 elements plus the ash content were determined by analytical procedures indicated in Table 1 . Those marked ' $\&$ ' in the table have their concentration levels near or below the detection $11 \mathrm{mit}$ and so are not further considered in the paper. Efficlent and rellable analytical procedures required that both whole-coal and coal ash be analyzed. Varlables for which whole coal was used to determine their concentration levels are $\mathrm{Au}, \mathrm{Hg}, \mathrm{As}, \mathrm{Cr}, \mathrm{Sb}, \mathrm{Sc}$, $T h, U, V$, and $S$. For the remaining variables, the levels of element concentration in the ash were recalculated to whole-coal equivalent.

Enrichment/depletion patterns are relative to the whole-coal sample, and ash values are 11sted for information (Figs. 3, 4 and 7). No threshold ratios vis-a-vis the clarke value are used when referring to the patterns which can be recognized in the data in terms of varying concentration levels. These are relative to where the prominent peaks occur in the channel samples.

The Shoemaker Seam, the small seam above the Harbour Seam, and the Unnamed Seam (F1g. 2), which are each $35 \mathrm{~cm}$ thick or less, are defined as thin seams (Table 2).

\section{COAL GEOCHEMISTRY}

To help understand the interpretation of the coal-chemical results, the nature of coal needs to be considered. Coal consists mainly of complex organic compounds. These can be classified into a serles of macerals (- microlithotypes) and represent the organic equivalent of minerals. In addition, coal contains detrita1, plant-derived and authigenic minerals (McCabe, 1984 and references therein). The authigenic minerals include those that are introduced in a peat swamp during or after its deposition, or in coal during or after the coalification process, 1.e., syn- or epigenetic mineral formation (Mackowsky, 1968). The properties of coal are therefore the result of 1ts depositional and diagenetic histories, and the composition of ash reflects the combined contributions from the organic compounds and the minerals, presenting a problem in correlation between organic complexes and minerals.

Coal mineralogy in the Sydney coals is dominated by iron disulfide minerals (pyrite, minor marcasite), clay minerals (1111te, kaolinite and chlorite). followed by at least another 20 minerals which include quartz and its variety chalcedony. Scanning electron microscopy (SEM) investigation, coupled with spectral analysis, shows that the clays are ubiquitous and occur intimately associated with the macerals and that in samples taken from the top of the seam sampled by Beaton (1986), anhedral pyrite and 1llite often occur together as cellular fillings in fusain (Bogan fusinite). This suggests fill-in as a model for pyrite origin and questions if the pyrite is detrital in origin. Additional investigations by chemical, SEM and X-ray microprobe methods reveal an association between pyrite and the elements $\mathrm{Cu}$. $\mathrm{N} 1, \mathrm{Se}, \mathrm{Hg}, \mathrm{As}, \mathrm{Sb}$ and $\mathrm{Pb}$ as expected. Based on work by Birk and Zodrow (In preparation), the major minerals (iron disulfide and the clays) are polygenetic in nature, as shown by microstructures of bedding, cell fillings, and replacement.

The sulfur component in the coal occurs as three types (Beaton, 1986): organic, sulfatic, and pyrit1c, whose sum-total weight percent constitutes total sulfur as recorded in Table 2. Of these, the organic sulfur is the least understood (Spiro et al., 1984). In a high-sulfur coal ( $S$ is larger than 1.5\%), about $80 \%$ of the total sulfur is pyrite-derived, the remaining $20 \%$ is split between the other two types in varying proportions (Beaton, 1986, Table 1). In contrast, in a low-sulfur coal pyrite is largely absent and the total sulfur content therein is determined by the organic type (Newman, 1935, p. 542). The inference therefore is that the correlation between sulfur and iron reflects the presence of pyrite (F1g. 7) only in the high sulfur coal. An example of a low-sulfur coal environment is represented by the Harbour-Seam sample 'CC' in Table 2.

The organic and the pyritic sulfur types are dependent on the distribution of the microlithotypes that comprise the coal, except that in a high-sulfur coal some portion of the pyritic component is epigenetic (Beaton, 1986). This epigenetic portion is derived from sulfate-rich solutions recycled from the Mississippian evaporite deposits 


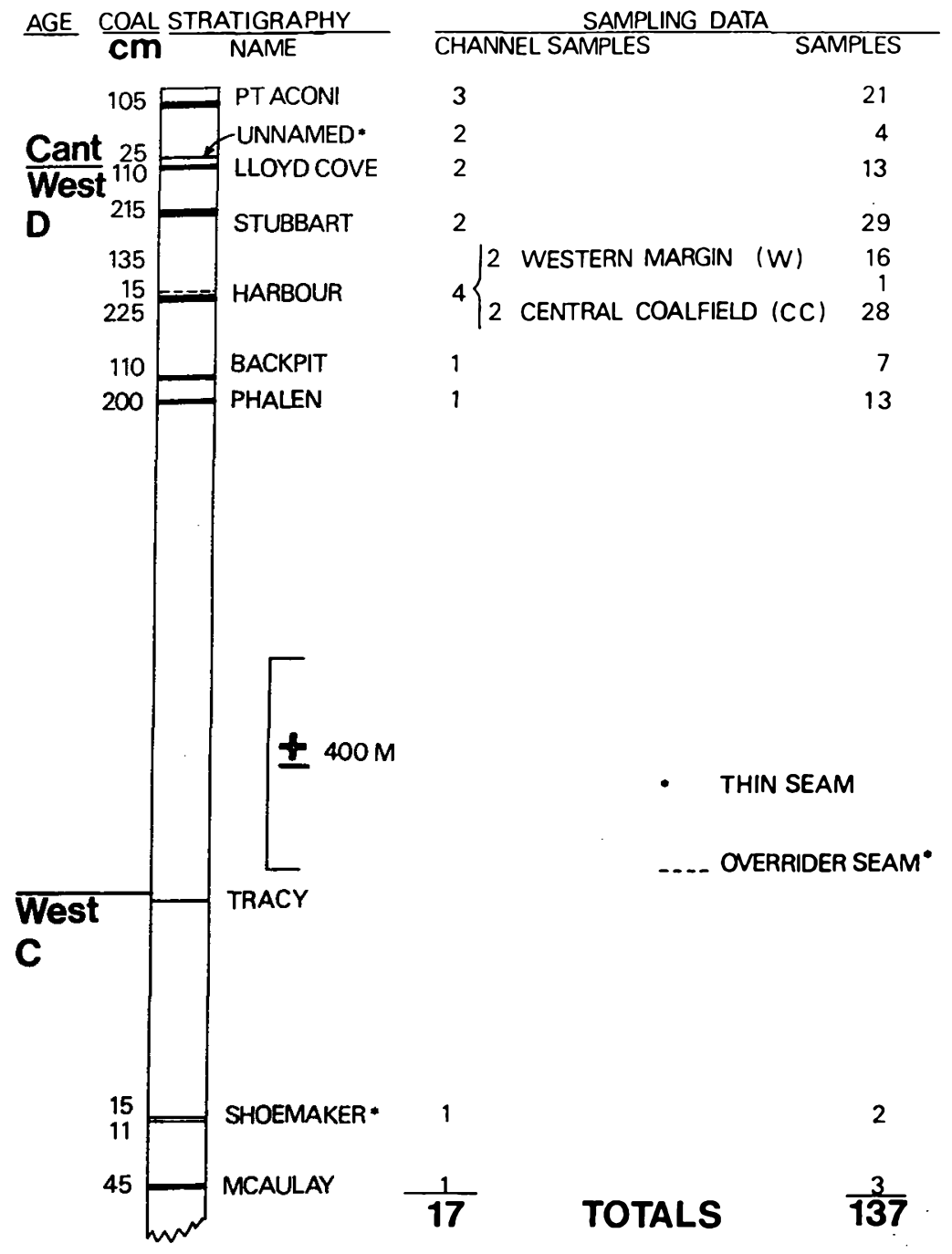

F1g. 2. Coal stratigraphy, Sydney Coalfleld, Nova Scotia (Be11, 1938, F1g. 1), showing channel sample data. 'Cant' refers to Cantabrian and 'West' to Westphalian Stages of the Upper Carboniferous System. 'CC' and ' $W$ ' are explained further in the text.

(Be11, 1938; Ha1tes, 1951; Gibling et al., 1986) that surround the Sydney Coalfield as the Windsor Group (see Kepple, 1979). The non-marine orlgin for the sulfur is supported by paleontology (Dawson, 1878; Be11, 1938; Copeland, 1957; Vasey and Zodrow, 1983; Vasey, 1984), and by boron geochemistry (Vasey and Zodrow, 1983).

\section{RESULTS AND DISCUSSION}

Geochemical results are stratigraphically summarized (youngest to oldest seam-sample representation) in Table 2 to show mean-value concentrations for a) Individual seam samples, b) thin- and thickseam samples, and c) laterally separate samples for the Harbour Seam.

On a between channe1-sample basis, the data reveal great varlability, no perceptible regional trend, and a suggestion of age dependency for the elements $\mathrm{Pb}, \mathrm{Zn}, \mathrm{Fe}, \mathrm{N} 1$ and $\mathrm{Cu}$, as their mean values are comparatively higher in the younger seam samples. The suggestion is supported by field observation of the combined presence of epigenetic galena, pyrite and chalcopyrite as cleat fillings in the roof portions of only the younger seams in the Point Acont area.

Most thin-seam elemental concentrations are, on average, higher than those in the thick-seam samples, correlating with high sulfur and ash averages in the thin seams. The evidence is, however, equivocal for $A u$, except for the Harbour ' $C C$ ' and McAulay values. The differences in concentrations are probably related to facles differences as explained by Kelser et al. (1982) and by Cheek and Donaldson (1969). The expected positive correlation between gold content and seam thickness, known from the ability of plants to concentrate gold (Krejc1-Graf, 1983, p. 541), is not evident from the data presented. The higher gold value in the McAulay Seam could 1ikely be epigenetically related to the known Carboniferous unconformity, in the vicinity of which many other mineralization events occurred on Cape Breton Island. As yet, the larger Se value remains to be explained. Ca and $\mathrm{Mn}$ abundances in the McAulay Seam reflect the presence of a calcium manganese mineral whose 1dentity is as yet undetermined.

More than one-half of the number of elements 
Table 1. Analytical methods and units of measurements

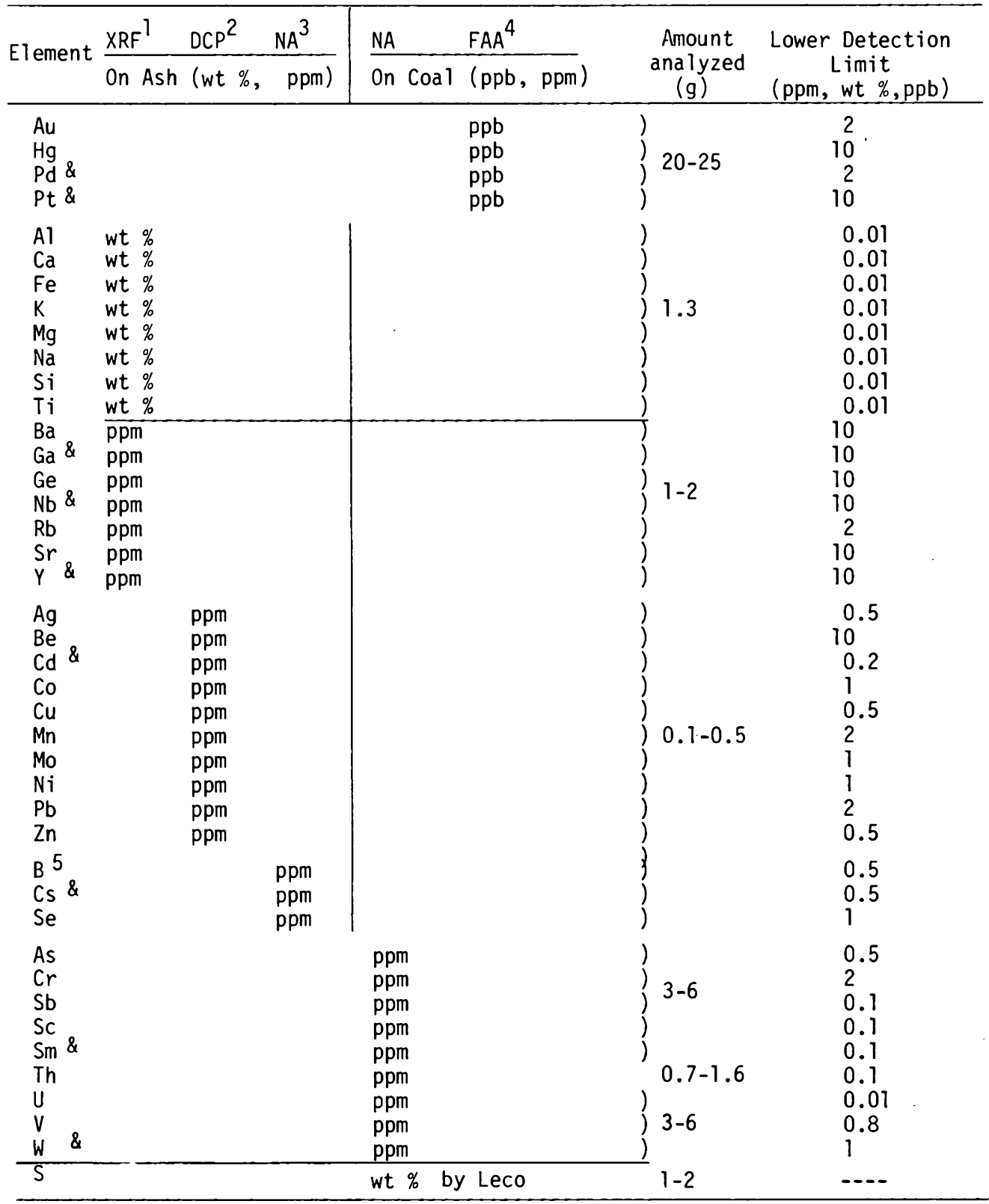

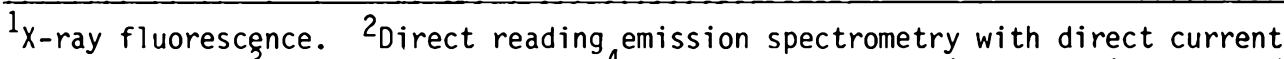
argon plasma. ${ }^{3}$ Neutron activation. ${ }^{4} \mathrm{Hg}$ by flameless atomic absorption; $\mathrm{Hg}, \mathrm{Pd}$ and Pt by fire assay collection with DCP of Doré bead. ${ }^{5}$ In two seams; not reported here. \& concentration levels near or below detection limit.

studied are on average more highly concentrated at the margin of the basin (Harbour-Seam sample ' $W$ ') than in the portion of the central coalfield (Harbour-Seam sample 'CC'), Including Be and $\mathrm{Ge}$. The distribution pattern is consistent with the assumption that both elements concentrated near their sources (Zubovic, 1966; Stadnichenko et al., 1953; Minchev and Eskenasy, 1966) and that the mineral content of the coal is detrital-dependent.

Within-sample varlability for most of the elements can be described in terms of relative enrichment/depletion patterns vis-à-vis coal thickness as follows:
1) either a) bottom and top are both enriched (F1g. 3a), or b) both bottom and top are depleted (Fig. 3b):

2) either a) bottom is depleted and top is enriched ( $\mathrm{F}_{\mathrm{g}}$. 3c), or b) top is depleted and bottom is enriched (Fig. 3d);

3) repetition of 1 ) or 2) in the sample.

The most common patterns conform with 1) and 2). but are variable for a given element from one seam sample to another.

Elements for which no pattern is discernible include Au (Stubbart sample), Mg (Harbour sample ' $W$ '), Rb (Pt. Acont sample), Sb (Phalen sample) and 
Table 2. Stratigraphic variation of sample mean+std

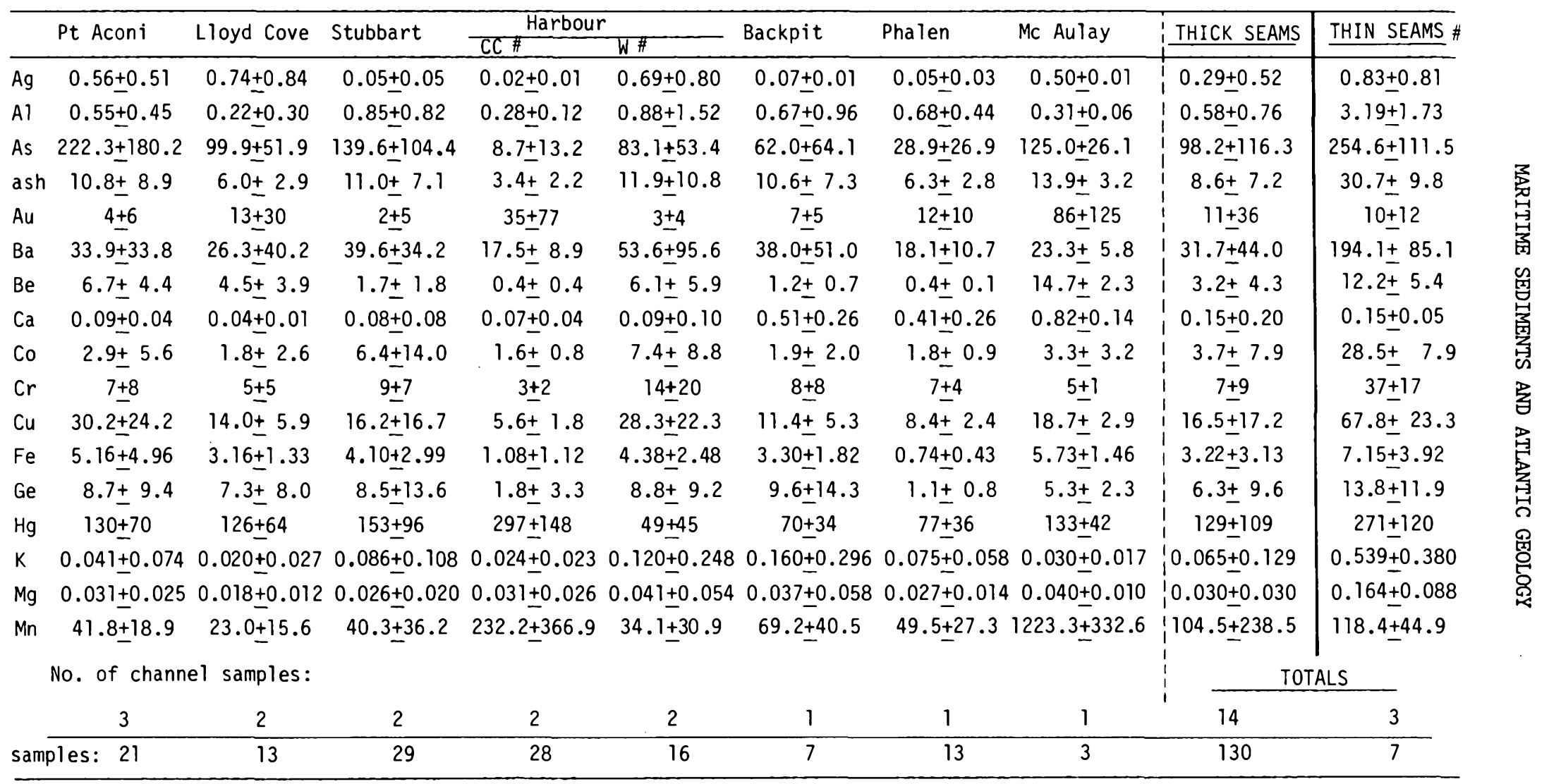

\# Refer to Fig. 2. 
Table 2. Continued

Stratigraphic variation of sample mean+std

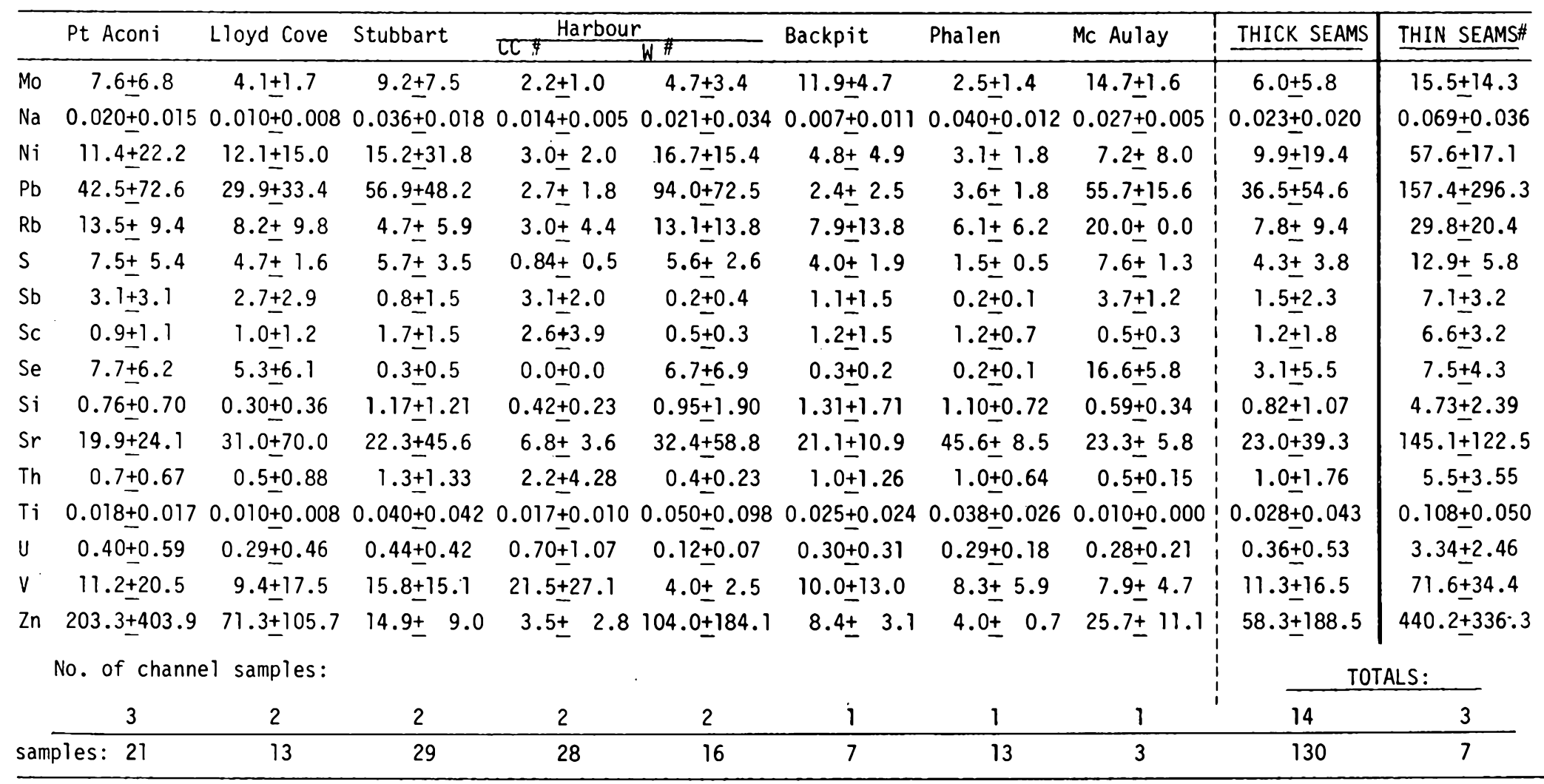

\# Refer to Fig. 2. 

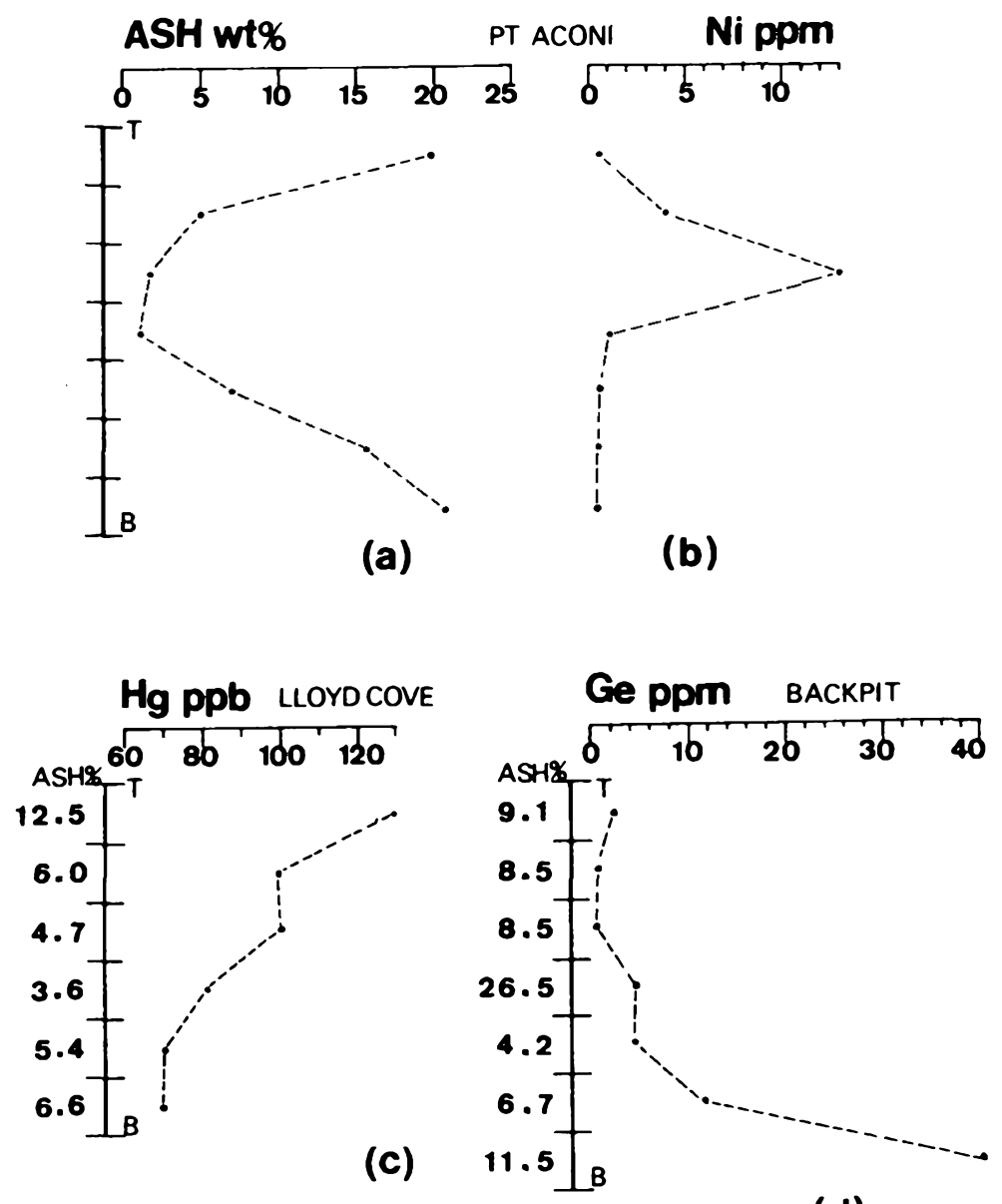

(d)

F1g. 3. Simple trend patterns in reference to the whole-coal channel samples that are indicated by the vertical black bars. 'T' refers to the top and ' $B$ ' to the bottom of the channel sample, in which $15 \mathrm{~cm}$ sample divisions are indicated by the horizontal cross bars (see also Figs. 3 and 6).

The coal ash percent (ASH\%) is listed for each $15 \mathrm{~cm}$ long sample to provide additional information.

T1 (Lloyd Cove sample). Pattern 3) is found where sample thickness is greater than $200 \mathrm{~cm}$ as in the Stubbart, Harbour ' $C C$ ' and Phalen seams. Usually; the geochemical varlables show complex trends in these three sample sites (F1g. 4). As in the case for the simple trends, the repetitive pattern 3) for a given variable may not be duplicated in the data from one sample to another.

The observed trend patterns preclude the use of a normal population model. Frequency analysis shows positively skewed histograms (e.g., Fig. 5) that are L-shaped, many of them unimodal at this level of sample size. Probability density modeling to investigate the underlying population suggests a Pearsonian Type I model (E1derton and Johnson, 1969) to represent the data. The Type I mode1 (Schuegraf and Zodrow, 1974) is based on the beta integral but has transformation potential to the log-normal model. Frequencies for U (Fig. 6), Th, $\mathrm{Pb}$ and $\mathrm{T} 1$ were fitted to the Type I Model with varying measures of success. The reader is cautioned about the difficulties, however, that exist with this sample size to decide on a model for data representation (Zodrow et al. , 1987).

The geochemical varlables $\mathrm{Ca}, \mathrm{Mn}, \mathrm{Sb}, \mathrm{Fe}, \mathrm{S} 1, \mathrm{~Pb}$ and $\mathrm{Zn}$ show large ranges (difference between smallest and largest data points), disjoint fre- quencies, or multimodal histograms in their sample distributions. These statistical characteristics are Indicative of the presence of several mineral phases for each varlable, involving sulfide, carbonate and sllicate groups.

Comparisons of skewness values among some of the presently studied variables and those from the U.S.A. (Gluskoter et al., 1977) and Australian (Slansky, 1985) coal samples show many similarities and notable differences. One difference is manifested by the smaller skewness values (i.e., 'better' symmetrical conditions) that are observed in histograms for coal ash in the other two coalfield samples, in comparison with the L-shaped frequency histogram of Sydney's coal ash (Fig. 5). It is suggested that the skewness differences reflect differing depositional environments, as is found in ash studies of modern-day peats (e.g. , Bustin et al., 1985).

\section{PATTERNS: GENETIC CONSIDERATION}

Simple trends, represented by 1a), reflect a situation of uninterrupted peat accumulation in a swamp. Increased interactions occurred between Iron-organic complexes (clay collolds) and sulfaterich solutions to deposit increasing amounts of 


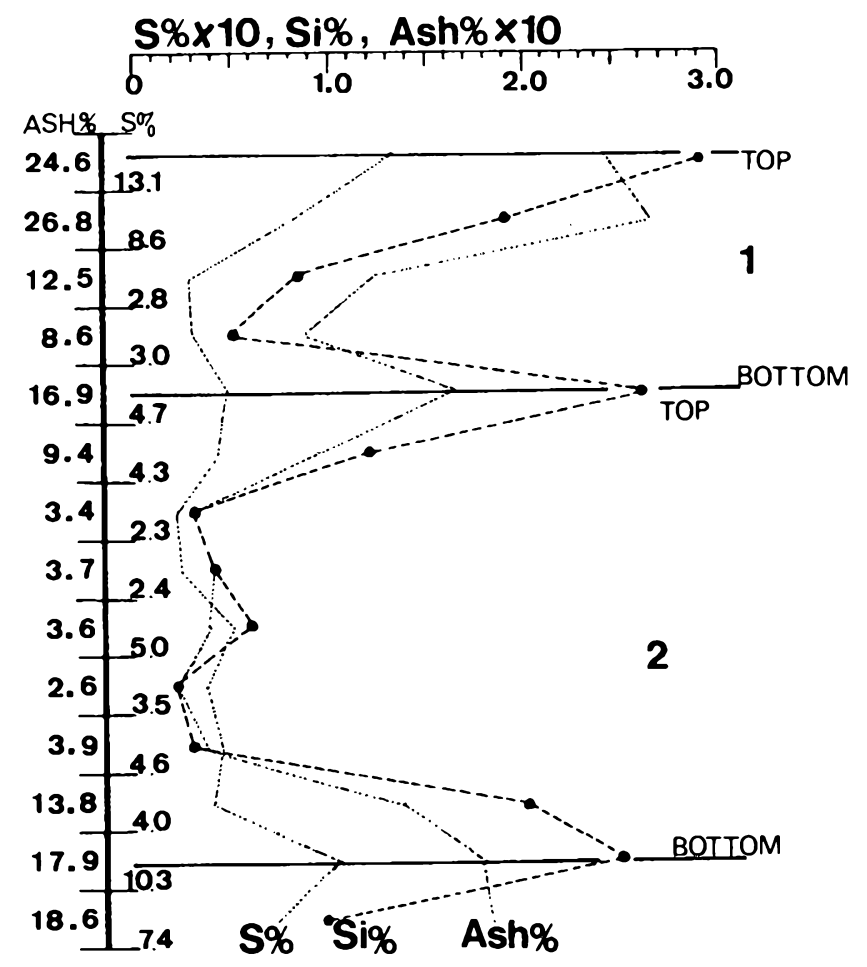

Fig. 4. Complex cyclical trend pattern in reference to the whole-coal channel sample from the Stubbart Seam. 'Topbottom 1 and $2^{\prime}$ each represent simple 1a) trend pattern analogues. The coal ash percent (ASH\%) and the sulfur content (S\%) are 11sted for each $15 \mathrm{~cm}$ long sample to provide additional information.

pyrite at the initial and terminal stages of peat accumulation (Newman, 1935; W111lams and Ke1th, 1963; N1cholls, 1968, p. 283). Peat accumulation continued in an environment progressively less affected by sedimentary influxes and in which poor drainage developed, resulting in lower ash and sulfur peat (unt11 the terminal-stage conditions are imposed). Fig. 7 represents the geochemical signature, showing high sulfur and ash at the bottom and roof of the Pt. Aconi Seam, with progressive decreases of these concentration levels towards the middle portion of the seam.

Patterns represented by $1 b)$ and $2 a, b)$ are mostly assoclated with the chalcophile elements and basic to their genesis is the complex polygenetic history of pyrite deposition.

Cyclical patterns can be broken down into simple patterns (Fig. 4). The interfaces defined at any two high/low concentration peaks represent a temporal initial/terminal stage situation, showing the enrichment/depletion patterns analogous to the simple pattern of 1a) and the distribution of sulfur and ash. This situation marks punctuated peat accumulation caused by influx of clayey sediments when levees are breached. The flooding events can be localized and discontinuous or extensive to form thicker sedimentary deposits that split the seams. These seam splits are macromanifestations of punctuated peat accumulation in a developing coal swamp. An exception to the varlability of patterns is found in the geochemical variables of the Backpit-Seam sample, where they show mostly la) trends. The nature of the roof rocks, lacustrine deposits in this case, may
Influence coal geochemistry as observed by McCabe (1984, p. 17-18), and Ha1tes (1950, p. 81).

\section{CONCLUSIONS}

Marine-influenced coal deposition is reflected in high-sulfur coal whose sulfur content is varlable both latera11y and vertically. In contrast, 1owsulfur coal shows comparatively less sulfur varlability. An unresolved problem is presented by the high-sulfur content that is also very varlable in the coals from the Sydney Coalfield, in the absence of marine incursions. The high variability also occurs in the ash and includes not only sulfur but all of the geochemical variables examined. This implies influxes of detrital minerals and authigenic mineral formation (which are reflected In the amount and composition of the coal ash; Nicholls, 1968, p. 283). Patterns can be simple or complex cyclical, but they could be refined through a study of shorter sample lengths than the $15 \mathrm{~cm}$ lengths employed. Additional1y, compaction ratios in peat-coal (McCabe, 1984, p. 2) and epigenetic mineralization undoubtediy influenced the distribution of the elements to form the observed pattern. In this context, the hypothesis by Goldschmidt (1937) that physical rather than geochemical
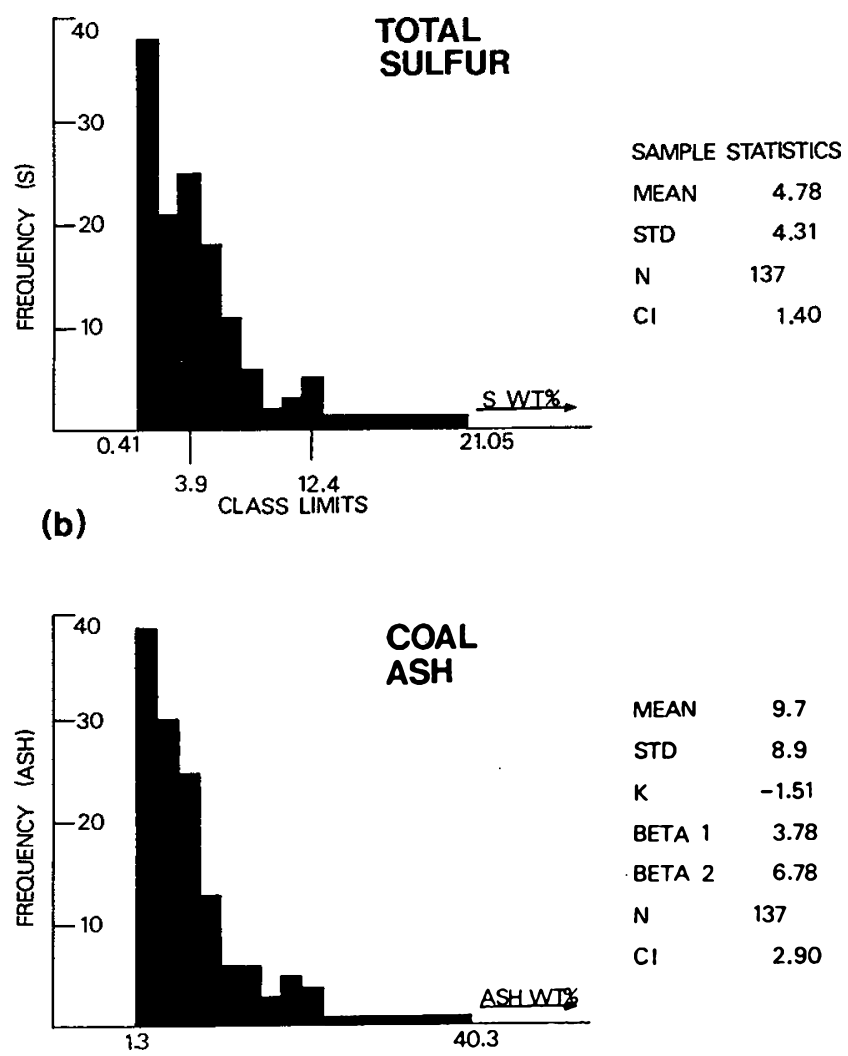

(a)

CLASS LIMITS

Fig. 5. Sample frequencles and statistics for sulfur and ash contents of the sample population. 'STD' is the standard deviation, ' $K$ ' the classification criterion for the Type I mode1, 'Beta 1 and Beta 2' skewness and kurtosis, respectively. ' $N$ ' the sample size, and ' $\mathrm{CI}$ ' is the class interval. The linear correlation coefficlent between sulfur and ash is 0.91 . 


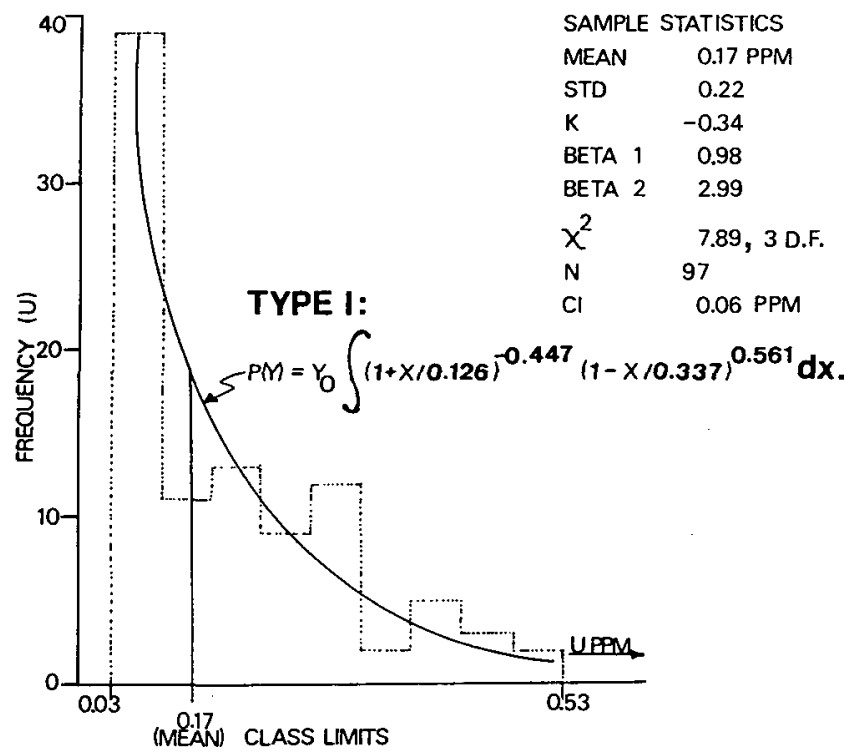

Fig. 6. Type I probability model (solid line) fitted to uranium frequencies (stippled bars). ' $P$ ' is the probability. ' $\mathrm{X}$ ' and 'D.F.' are the "goodness-of-fit" statistic and associate number of degrees of freedom.

Refer to Fig. 4 for explanation of other letters used.

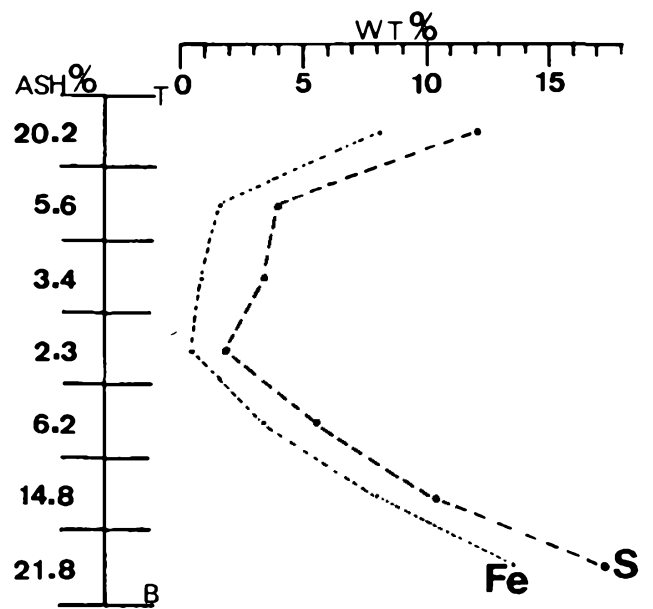

Fig. 7. Uninterrupted peat accumulation in the Pt. Aconi coal and 1ts geochemical signature of sulfur and iron (pyrite correlative) in the setting of ash content (ASH\%) variation. The simple 1a) patterns for $\mathrm{S}$ and $\mathrm{Fe}$ are in reference to the whole-coal sample.

phenomena are responsible for the patterns remains to be confirmed.

The results obtained by Hawley (1955), 1.e., that microlithotypes correlate poorly with trace elements and it is difficult to correlate coal seams on that basis, are not surprising in view of the variability of geochemical trends in the coal. Hacquebard's suggestion (1986) for the use of petrological profiles for correlation is probably the best viable alternative. Clearly, grab or runof-the-mine samples (cf. Landheer et al., 1982; Sandeman, 1979) can only furnish blased mean values for coal. Of possible mineral exploration interest is the observation that in the younger seams, near the Permo-Carboniferous boundary, increased sulfide mineralization was found.
Note added in proof: Recent discoveries of foraminifera, fragments of conodonts and cephalopods by S. Thibaudeau of Dalhousie University, Halifax, Nova Scotia (personal communication, September 1987) constitute positive proof for the first time of marginal marine influences in the Sydney Coalfield.

\section{ACKNOWLEDGEMENTS}

The study was supported by N.S.E.R.C. Canada for which the author is grateful. Equally, I express my gratitude to reviewers of the Journal for their help with the typescript and to Prof. Dr. K. Krejc1-Graf and Dr. F. Goodarzi for comments and suggestions.

BEATON, A.P. 1986. Stratigraphic sulfur form distribution in the Harbour Seam, Sydney, N.S. Unpublished B.Sc. thesis, St. Francis Xavier University. Antigonish, Nova Scotia. 63 pp. plus two appendices.

BELL, W.A. 1938. Fossil flora of Sydney Coalfield. Geological Survey of Canada, Memoir 215, $334 \mathrm{p}$.

BUSTIN R.M. STYAN, W.S. and LOWE, L.E. 1985. Variability of sulfur and ash in humid-temperate peats of the Fraser River Delta, British Columbia. In Dixieme Congrès International de Stratigraphie et de Géologie du Carbonifère, Compte Rendu. Edited by J.L. Escobedo, L.F. Granados, B. Melendez, P. Pignatel11, R. Rey and R.H. Wagner. Madr1d, 1983, 2, pp. 79-

CHEEK, R. and DONALDSON, A. 1969. Sulfur facies of the Upper Freeport Coal of northwestern Preston County. West Virginia. In Some Appalachian Coals and Carbonates: Models of Ancient Shallow-water Deposition. Edited by A.C. Donaldson. Preconvention G.S.A. Field Trip, November 1969. West Virginia Geological and Economic Survey, Morgantown, pp. 279-307.

COPELAND, M.J. 1957. The arthropod fauna of the Upper Carboniferous rocks of the Maritime Provinces. Geological Survey of Canada, Memoir 286, 110 p.

DAWSON, J.W. 1878. Acadian geology. 3rd edit1on Macmillan, London, $694 \mathrm{p}$.

ELDERTON, W.P. and JOHNSON, L.N. 1969. Systems of frequency curves. Cambridge University Press, 216 p.

GIBLING, M.R., ZENTILLI, M. MAHONY, H. and McREADY, R.G.L. 1986. Did sulphur in the Sydney Coal come from the Windsor Group Evaporites? In Current Research, Part B, Geological Survey of Canada. Paper 86-1B. Pp. 73-76.

GIVEN, P.H. WELDON, D. and SHUR, N. 1981. Investigation of the distribution of minerals in coals by normative analysis. Pennsylvanian State University Technical Report 2L (Coal Research Section, Department of Material Science and Engineering), 1, pp. 1-27.

GLUSKOTER, H.J.. RUCH, R.R.. MILLER, W.G., CAHILL, R.A., DREHER, G.B. and KUHN, J.K. 1977. Trace elements in coal: Occurrence and Distribution. Illinois State Geological Survey, Circular 499, $154 \mathrm{p}$.

GOLDSCHMIDT, V.M. 1935. Rare elements in coal ashes. Industrial and Engineering Chemistry, 27 (9). pp. 1100-1102.

GOLDSCHMIDT, V.M. 1937. The principles of distribution of chemical elements in minerals and rocks. Journal of the Chemical Society, London, Part I. pp. 655-673.

HACQUEBARD, P.A. 1983. Geological development and economic evaluation of the Sydney Coal Basin. Nova Scotia. In Current Research, Part A, Geological Survey of Canada, Paper 83-1A. pp. 71-81.

HACQUEBARD P.A. 1986. The Gulf of St. Lawrence Carboniferous Basin; the largest coalfield of eastern Canada. CIM Bulletin, $79(891)$. pp. $67-78$.

HAITES. T.B. 1950. Some geological aspects of the Sydney coal field with reference to their influence on mining operations. In Conference on The Origin and Constitution of Coal. Nova Scotia Department of Mines and Nova Scotia Research Foundation, Crystal Cliffs, Nova Scotia, p. 159.

HAITES, T.B. 1951. Some geological aspects of the Sydney Coalfield with reference to their influence on mining operations. The Canadian Mining and Metallurgical Bulletin. 44(469), pp. 329-339.

HAWLEY, J.E. 1955. Spectrographic study of some Nova Scotia coals. Canadian Institute of Mining and Metallurgy. Transactions, 58, pp. 412-426.

KEISER, A.F., REPPERT, R.S., BLAKE, B.M. and TRINKLE, E.J. 1982. Low-sulfur coals of southern West Virginia: A 
Depositional Mode1. Mining Englneering of AIME, Transactions, 272, pp. 1812-1820.

KEPPIE, D.J. Compiler. 1979. Geological map of the Province of Nova Scotla (scale 1:500.000). Department of Mines and Energy. Nova Scot1a, Canada.

KREJCI-GRAF. K. 1983. Minor elements in coals. In The Significance of Trace Elements in solving petrogenetic Problems and Controversies. Edited by S.S. August1th1s, Theophrastus Publications S.A., pp. 533-597.

LANDHEER, F. . DIBBS, H. and LABUDA, J. 1982. Trace elements in Canadian coals. Environment Canada, Report EPS 3-AP-82-6, 41

MacKOWSKY, M.-Th. 1968. Mineral matter in coal. In Coal and Coal-bear1ng Strata. Edited by D. Murch1son and T.S. Westoll. American Elsevier Publishing Company. Incorporated, pp. 309321

McCABE. P.J. 1984. Depositional environments of coal and coalbearing strata. Special Publication of the International Association of Sedimentologists, 7 pp. 13-42.

MINCHEV, D. and ESKENASY. Gr. 1966. Trace elements in the coals of Bulgarla. Germanium and other trace elements in the coals of the Vulche-Pole Deposit--East Rhodope Mountain. Annuaire de 1'Université de Sofia, Facultes de Gelogle et Geographie, 59(1). pp. 357-371.

NICHOLLS, G.D. 1968. The geochem1stry of coal-bearing strata. In Coal and Coal-bearing Strata. Edited by D. Murchison and T.S. Westoll. American Elsevier Publication Company. Incorporated, Ol1ver Boyd, Edinburgh, pp. 269-307.

NEWMAN, W.R. 1935. Microscopic features of the Phalen Seam, Sydney Coalfield, Nova Scotla. Canadian Journal of Research, 12. pp. 533-553.

SANDEMAN, M.R. 1979. Thermal and ep1thermal neutron activation analysis of Nova Scotia raw and washed coals. Unpublished M.Sc. thesis, Dalhousie University, Halifax, Nova Scot1a, 122 pp.

SCHUEGRAF, E.J. and ZODROW, E.L. 1974. Fortran IV program to compute Pearson's frequency curves. Computers and Geosciences, 1, pp. 75-81.

SLANSKY, J.M. 1985. Distribution of 1norganic chemical elements in coal seams of the Sydney Basin New South Wales Australia (a statistical study). In Dixieme Congrès International de Stratigraphie et de Géologie du Carbonifere, Compte
Rendu. Edited by J.L. Escobedo, L.R. Granados, B. Melèndez R. Pignatell1. R. Rey and R.H. Wagner. Madrid, 3. pp. 415432.

SPIRO, C.L. WONG, J. LYTLE, F.W. , GREEGOR, R.B. . MAYLOTTE, D.H. and LAMSON, S.H. 1984. X-ray absorption spectroscopic investigation of sulfur sites in coal: organic sulfur 1dent1fication. Science, 226, pp. 48-50.

STADNICHENKO, T. MURATA, K.J. ZUBOVIC, P. and HUFSCHMIDT, E.L. 1953. Concentration of germanium in the ash of American coals. United States Geological Survey. C1rcular 272.

TAYLOR, S.R. 1964. Abundance of chemical elements in the cont1nental crust: a new table. Geochimica et Cosmochimica Acta. 28, pp. $1273-1285$

VASEY, G.M. 1984. Westphalian macrofaunas in Nova Scotia: paleontology and correlation. Unpublished Ph.D. Thesis. Strathclyde University. Glasgow, Scotland, 467 pp.

VASEY, G.M. and ZODROW, E.L. 1983. Environmental and correlative significance of a non-marine algal limestone (Westphalian D) Sydney Coalfield Cape Breton Island, Nova Scot1a. Maritime Sediments and.Atlantic Geology. 19, pp. 1-10.

WALSH, J.H., VISMAN, J.. WHALLEY, B.J.P. and AHMED, S.M. 1969. Removal of pyrite from Cape Breton coals destined for use in metallurgical processes. In Ninth Comnonwealth Mining and Metallurgical Congress 1969. Paper 35, pp. 1-35.

WILLIAMS, E.G. and KBITH, M.L. 1963. Relat1onsh1p between sulfur in coals and the occurrence of marine roof beds. Economic Geology. 58, pp. 720-729.

ZODROW, E.L. 1983. Some geochemical aspects of sedimentary rocks in proximity of coals. Sydney Coalfield (Upper Carboniferous). Cape Breton Island, Nova Scotia, Canada. International Journal of Coal Geology, 2, pp. 299-320.

ZODROW, E.L. 1985. Odontopteris Brongniart in the Upper Carboniferous of Canada. Palaeontographica Abt.B., 196. pp. 79-110.

ZODROW, E.L., BANERJEE, S.K. and JESSOME, D.R. 1987. Uranium content and distribution in whole-coal samples. Sydney Coalfield (Upper Carboniferous), Nova Scotia, Canada. International Journal of Coal Geology. 8. pp. 299-303.

ZUBOVIC. P. 1966. Minor element distribution in coal samples of the Interior Coal Province. In Coal Sclence. American Chemical Soclety. Advances in Chemistry. 55. pp. 232-247. 